\title{
Assessment of the Factors Affecting Accuracy of Pre-tender Cost Estimate in Kaduna State, Nigeria
}

\author{
Polycarp Olaku Alumbugu ${ }^{1 *}$, Wasiu Adeniran Ola-awo ${ }^{2}$ SAIDU, Ibrahim ${ }^{3}$ \\ ABDULLAHI, Mustapha Muhammed ${ }^{4}$ and Abdulmumin Abdulazeez ${ }^{5}$ \\ ${ }^{1,2,3,4,5}$ Department of Quantity Surveying, Federal University of Technology, P.M.B. 65, Minna, Niger State, \\ Nigeria.
}

\begin{abstract}
Accurate cost estimates are crucial to the effective realisation of construction projects. Researchers have noticed the presence of inherent inaccuracies in the bill of quantities prepared by estimators (Quantity surveyors). This paper aimed at examining the factors affecting accuracy of pre-tender cost estimate in Kaduna state, with a view to improving the predictive ability of clients, consultants, and contractors for better estimating. A total of 66 questionnaires were administered with 35 to consultants (53.03\%), 15 to contractors (22.73\%) and 16 (24.24\%) to clients within Kaduna using the simple random sampling technique. The collected data were analysed using the Relative Importance Index and correlation analysis. The study found out that a statistically significant relationship existed between the clients, consultants, and contractor on the essential factors affecting accuracy of pre-tender cost estimate. It was concluded that: Experience and skill level of the consultants, Project teams experience on the construction type, clear and detail drawings and specification, completeness of cost information, accuracy and reliability of cost information are the most significant factors affecting accuracy of pre-tender cost estimate. It was recommended that Clients should always engage the services of skilled professionals to undertake the consultancy services in cost estimating process.
\end{abstract}

Key words: Accuracy-estimation, Pre- tender and Cost estimate.

\section{Introduction}

Improvement in the construction industry will probably lead to an improvement in the Nigerian economy. This can be achieved by improving the construction project management aspect. The success rate or otherwise of a project depends on the degree of accuracy of the estimates. Estimates have to be as accurate as possible because these make up the basis for tender comparison, assessment, evaluation or negotiations. If these estimates are grossly inadequate, award decisions may be extremely difficult (Trost \& Oberlender, 2003).

In virtually all contracts, preparing a realistic cost estimate is an essential component of any construction operation. Pre-tender cost estimation is early stage cost estimation and is the forecasting of the cost of a project during the planning and design stage (Serpell, 2005). This estimate serves as basis for financial support decisions and cost control. At the pre-tender stage, clients are interested in knowing the total project cost commitments. But cost estimation at the pre-tender stage is vulnerable to inaccuracy (bias) because they are frequently prepared within a narrow time frame, and often devoid of finalized project scope. Over and underestimation of cost have potent effects on a project. The former may cause the client to spend more resources for no beneficial matters or discourage financing institutions from lending the required amount of money due to doubts regarding the cost and resultant benefits of the project, while the latter may lead to downsizing the project scope and eventual abandonment.

Estimates are the basis upon which tender comparison and negotiations are carried out. An overestimation a particular project means lesser (minimal) resources would be available for other projects. And, an under estimation may result to unrealistic negotiation (Odusami \& Onukwube, 2008). A significant part of the construction procurement process that needs proper attention is the management of client expenditure. This is usually carried out by means of a budgetary control which involves the setting of realistic project budgets and the subsequent monitoring of client expenditure (Skitmore \& Picken, 2000).

Most tenders were substantially won and lost on price alone, it has been observed that the final price paid by most clients are different from the price tendered by the contractor. In a competitive contract, majority of contractors with the lowest bidder often win the contract. Nevertheless this bid must not be so low that it might lead to completing the work without profit (Al-Khaldi, 1990). Therefore, the preparation of an accurate estimate, which is done prior to the physical realization of the work, demands detailed study of the bid document vis-à-vis the environmental situation. This thus involves a careful and cautious examination of the outcome of the study so as to come up with the most accurate estimate of the likely cost consistent with the time on hand, the accuracy and completeness of the information submitted (Abdal-Hadi, 2010). In view of the significance of accuracy of pre-tender cost estimate, it is assumed that identifying these factors which have 
effect on the accuracy of pre-tender cost estimate and reflecting on them at the early design stage can improve the accuracy and precision of the preliminary cost advice of the consultant quantity surveyor to his client.Pretender cost estimate is an attempt to forecast a contractor's tender sum before detailed designs are finalized or upon the receipt of tenders, is undertaken by the consultant quantity surveyor on behalf of his client. There is therefore the need for estimates to be as accurate as possible (Odusami \& Onukwube, 2008).

A large number of factors have effects on cost. Meaning and explanation can be given to this, taking cognizance of the multidisciplinary nature of the construction industry and its works, which fuse together the combine efforts of the owner, the professionals, the contractors and suppliers. Proper integration of the combine efforts of these parties from the design table to the implementation or execution of projects will show significant effects on the overall project cost.

Previous researches in Nigeria were based on perception of one stakeholder. For instance Odusami \& Onukwube (2008), Oladokun, Oladokun, \& Odesola (2010) worked from the perspective of the consultants in Lagos state only. None of these authors considered Kaduna which this paper considered. The study area is chosen because of large number of constructions and consultants firms and because of the proximity to Abuja, Nigeria federal capital. Most of the firms working in Abuja have their head offices in Kaduna.

The problem of inaccurate cost estimate reflected by the increasingly large number of projects being completed with time and cost overrun. By identifying the factors responsible for the inaccuracy in a pre-tender cost estimate it would surely improve on project delivery. Improving tendering efficiency that will be of benefits to clients, consulting firms and it would provide contractors better ways to improve on their method of tendering. There is dearth of literature on the factors affecting accuracy of pre-tender cost estimate in most part of developed countries from the perspective of the clients, consultant and contractor. It is worrisome that in Nigeria group perception is lacking most especially in Kaduna, hence the need for this study.

The aim of this paper is to examine the most important factors affecting accuracy of pre-tender cost estimate in Kaduna state, Nigeria, in order to improve the predictive ability of client, consultants and contractor for better estimating. The paper also evaluate the degree of agreement between clients, contractors and consultant on the ranking of these factors

\section{Factors affecting the accuracy of cost estimate}

A lot of factors have effect on the accuracy of cost estimates of construction projects such as availability of materials on the local market, expertise of consultant, quality of information and flow requirement, inflation etc. These factors should be taken into account in the early stage of an estimate. Some of these factors can increase costs and the possibility of contractual disputes between the various parties involved, while some of the factors can lead the estimator to decrease the cost of an item for successful tendering in a very competitive market.

Onukwube (2002) recognized tender as an offer made by a contractor to construct building in accordance with the condition of contract within a quoted period for a sum of money. It is thus a heavily experience-based process, which involves evaluations of unknown circumstances and complex relationships of cost-influencing factors (Elhag Boussabaine, \& Ballal, 2005).

Hendrickson (2000) identified three types of cost estimates as: design estimate: bid estimate and control estimate. Ashworth (1999) and Aliyu (2005) identified estimating types as: preliminary cost, feasibility cost estimate, viability cost estimate, authorization cost estimate, final budget cost estimate and control cost estimate. Project cost depends not only on a single factor but a cluster of variables related to the characteristics of the project and the construction team (Chan \& Park, 2005). Onukwube (2002) identified 15 factors influencing tender prices: as volume of building projects with back up finance, degree of competition among contractors, other factors are, project definition, contracting plan, type of development, labor productivity, material availability, contract types, location/site conditions, management ability, zonal rates, category of contractor, level of profit, level of workmanship, and government policy.

In the early phases of a project, estimates of cost are made without detailed drawing or other means of determining what the building will be. More often than not, these estimates are based upon assumptions, past experience, and creative visualizations of the likely direction and form the construction of the building will follow/take. Estimates at this phase are somewhat rough approximations. As the work goes on, the techniques and the estimates themselves will be refined more and more to reflect the scope and decisions taken along the way. Before the tendering phase, the estimates will have been refined to a very high degree of accuracy (Momoh, 1980).

Aseidu \& Gu (1998) viewed the accuracy of an estimate as having an inverse proportionality to the time between which the estimate was prepared and the actual event. Accurate estimation of construction costs is heavily dependent on the availability of qualitative historical cost data and professional expertise among other things. The limited available information at the early project construction stage may cause the quantity surveyor to make assumptions as regards the detail design of a project, which may or may not eventuate as the design, 
planning, and construction evolve (Liu \& Zhu, 2007). The accuracy of an estimate is measured by how well the estimated cost compares to the actual total cost. There are four determinants of the accuracy of an early estimate: (1) the person who prepared the estimate; (2) the manner in which the estimate was prepared; (3) project information; and (4) other factors that were considered while preparing the estimate (Oberlender \& Trost 2001).

Aliyu (2005) revealed 25 factors influencing the accuracy of cost estimate such as: complexity of design and construction, location of project, project organization, site constraint, experience of consultant, duration between estimate and commencement of work, completion period of work, inflation on cost of materials, number of competitors, quality of information flow, accuracy of BOQ, availability of skilled labor, procurement method, magnitude of variation order, method of payment, type of employer, financial status of employer, financial status of contractor, volume and value of workload, equipment and their condition, period of execution, expected natural forces, clarity and quality of drawing, value of specialist work, and prefabricated works were all recognized. Iyer \& Jha (2005) asserted that the presence of conflict among parties to the project, availability of poor project attributes, hostile socio economic relations and poor climatic conditions, competitive tendering, and short time allowed for preparing bids, have adverse effect on cost of construction.

Dysert (2006), enumerated the factors affecting estimate accuracy to include, project definition, the quality of reference cost estimating data, the quality of assumptions from which the estimate are prepared, technological advancement in the project, the experience and skill level of the estimator, specific estimating techniques employed, the desired use of the estimate, the effort put into preparing the estimate, and extraneous market conditions. With other factors being; capability of the project team to control the project and the capability to adjust the estimate for scope changes as the project develops.

Odusami and Onukwube (2008) identified seven (7) most important factors affecting pre-tender cost estimate in Lagos State as: expertise of consultants, quality of information and flow requirements, project team's experience of the construction type, tender period and market condition, extent of completion of pre-contract design, complexity of design and construction, availability and supplies of labor and materials. In examining the factors influencing cost estimating practice, Akintoye (2000), identified complexity of the project, scale and scope of construction, site constraints, financial position of the client, build ability and project location, as the main factors. Shash \& Ibrahim (2005), examined the factors and procedures adopted in eastern province of Saudi Arabia by consulting firms in the selection of appropriate early cost estimating technique, the result indicated size of the project as the most important factor in selecting the estimating technique to be used; others are availability of information, client, project type, available time, experience of the estimator, construction method, and design variables while Expected number of bidders ranked least, with an importance index of 60.00 .

\section{Purpose of preparing pre-tender cost estimate}

Pre-tender cost estimate purpose is to give an indication of the most likely cost of construction at the earliest phase of a construction project. Approximate estimates on the high side cause make the client to reconsider the project scope or worse discourages him from furthering the scheme (lost opportunities). Conversely, an estimate that is too low may lead to client dissatisfaction, abortive or wasted development efforts, or litigation (Shash \& Ibrahim, 2005). The reliability of anticipating and predicting the amount of the contractor's tender therefore depends on its disparity from the final completion cost of the project. As such, the pre- tender sum(s) remains the major index for measuring the reliability/accuracy of the Consultant Quantity Surveyors estimate. According to Antohie (2009), an estimate serves the purpose of postulating the required costs of completing a project in line with set out specifications and contract plans.

Marjuki,( 2006) outlines the purpose of a cost estimate as:

a. Provides an assessment of capital cost for a specified piece of work.

b. The basis for planning and control by defining the scope of work and its associated estimated cost.

c. Provides much of the basic information (hours, resources, tasks, and durations) needed for schedule preparation, including labor, material, and construction equipment requirements.

d. Provides financial input needed for preparing cash flow curves.

e. Is a catalyst for discussion, idea generation, teaming participation, clarity and buy-in, it ties together much of the relevant project information within a simple document.

\section{Research Methodology}

The targeted population of this research was primarily the clients, contractors and consultant located within Kaduna metropolis. 102 well structured questionnaires were randomly distributed as follows: 28 to contractors, 26 to clients, and 48 went to the consultant firms but only 66 were returned (65\%) and analysed in the following pattern: 35 from consultants (53.03\%), 15 from contractors $(22.73 \%)$ and $16(24.24 \%)$ from client organisations. 
The factors affecting accuracy of pre-tender cost estimate were identified to be 54 from literature and subjected to ranking based on the opinions of respondents within the study area. The identified factors were examined on a 5 point likert scale ranging from 5 (extremely significant) to 1 (not significant). The relative important indices (RII) for each factor were computed using Microsoft Office Excel 2007 based on the formula below:

$$
\text { RII }=\frac{\Sigma \text { w }}{\text { A x N }}
$$

Where:

$\mathrm{W}=$ denotes the weight of each factor given by the respondents in the range of 1 to 5

$\mathrm{A}=$ the highest weight in the scale "5"

$\mathrm{N}=$ the total number of respondents (Morenikeji, 2006)

The paper evaluated the degree of agreement or disagreement regarding the ranking of these factors.

The spearman rank correlation was use to established the degree of agreement, between two variables on a ranked order. $\mathrm{R}$ " is the coefficient of correlation and ranges from +1 to -1 . While $\mathrm{R}^{2}$ called the coefficient of determination and is expressed in percentage (\%). The value of " $\mathrm{R}$ " at $50 \%$ and above is considered to be at significant level.

\section{Results and Discussion}

Experience and Skill Level of the Consultants (ESLC) is the first and most important factor affecting the accuracy of pre-tender cost estimate, going by the ranking of all categories of the respondents, with RII of 0.90 . Although it also ranked $3^{\text {rd }}$ with RII of 0.83 by the clients and ranked $24^{\text {th }}$ with RII 0.65 by consultants, and $1^{\text {st }}$ with 0.87 by the contractors. Project Teams Experience on the Construction Type (PTECT) was ranked $2^{\text {nd }}$ with RII of 0.89 . but the same factor was ranked $3^{\text {rd }}$ with RII of 0.83 by the clients, $10^{\text {th }}$ with RII 0.80 by consultants, and ranked $2^{\text {nd }}$ with RII 0.84 by the contractors. Clear and Detail Drawings and Specification (CDDS) was ranked $3^{\text {rd }}$ with RII 0.87 as ranked by all categories of the respondents. This factor was ranked $1^{\text {st }}$ with RII 0.86 by the clients, $23^{\text {rd }}$ with RII 0.66 by the consultants, and $1^{\text {st }}$ with RII 0.84 by the contractors.

Completeness of Cost Information (CCI) as a factor was ranked $4^{\text {th }}$ overall with RII 0.84 . The clients ranked it 4th with RII 0.81; consultants ranked it 25 th with 0.63 , and contractors, $3^{\text {rd }}$ position with RII 0.83 . Accuracy and Reliability of Cost Information (ARCI) had overall ranking of $5^{\text {th }}$ with RII of 0.83 . Availability of all field of specialization in a project team (AAFS) was ranked $6^{\text {th }}$ in overall ranking by the respondents. This same factor was ranked $7^{\text {th }}$ with RII of 0.78 by the client and $7^{\text {th }}$ with RII of 0.83 by consultants and contractors also ranked it $3^{\text {rd }}$ with RII of .83 .

Quality of information and flow requirements (QIFR) was ranked $7^{\text {th }}$ in the overall ranking of the respondents. Although, clients ranked it $8^{\text {th }}$ with RII of 0.76 , while consultant ranked it $5^{\text {th }}$ with RII of 0.86 . The contractor ranked it $8^{\text {th }}$ with RII of0.76.

Financial capability of the client (FCC) was also ranked $8^{\text {th }}$ with RII of 0.80 by overall ranking of the respondents. Client ranked the same factor $6^{\text {th }}$ with RII of 0.79 and consultants ranked it $3^{\text {rd }}$ with RII of 0.88 and $5^{\text {th }}$ with RII of 0.80 .

The same factor was ranked $8^{\text {th }}$ by the clients with RII $0.76,12^{\text {th }}$ by the consultants with RII 0.78 , and $3^{\text {rd }}$ with RII 0.83 by the contractors.

\begin{tabular}{|c|c|c|c|c|c|c|c|c|c|}
\hline $\mathrm{S} / \mathrm{N}$ & Factors & $\begin{array}{c}\text { Overall } \\
\text { RII }\end{array}$ & $\begin{array}{l}\text { Overall } \\
\text { ranking }\end{array}$ & $\begin{array}{c}\text { Client } \\
\text { RII }\end{array}$ & $\begin{array}{c}\text { Client } \\
\text { ranking }\end{array}$ & $\begin{array}{c}\text { Consultants } \\
\text { RII }\end{array}$ & $\begin{array}{l}\text { Consultants } \\
\text { ranking }\end{array}$ & $\begin{array}{c}\text { Contractor } \\
\text { RII }\end{array}$ & $\begin{array}{c}\text { Contractor } \\
\text { ranking }\end{array}$ \\
\hline 1 & ESLC & 0.9 & 1 & 0.83 & 3 & 0.65 & 24 & 0.87 & 1 \\
\hline 2 & PTECT & 0.89 & 2 & 0.83 & 3 & 0.8 & 10 & 0.84 & 2 \\
\hline 3 & CDDS & 0.87 & 3 & 0.86 & 1 & 0.66 & 23 & 0.87 & 1 \\
\hline 4 & CCI & 0.84 & 4 & 0.81 & 4 & 0.63 & 25 & 0.83 & 3 \\
\hline 5 & ARCI & 0.83 & 5 & 0.76 & 8 & 0.78 & 12 & 0.83 & 3 \\
\hline 6 & AAFS & 0.82 & 6 & 0.78 & 7 & 0.83 & 7 & 0.83 & 3 \\
\hline 7 & QIFR & 0.81 & 7 & 0.76 & 8 & 0.86 & 5 & 0.76 & 8 \\
\hline 8 & CSDC & 0.8 & 8 & 0.78 & 7 & 0.87 & 4 & 0.79 & 6 \\
\hline 9 & FCC & 0.8 & 8 & 0.79 & 6 & 0.88 & 3 & 0.8 & 5 \\
\hline 10 & CPD & 0.79 & 9 & 0.75 & 9 & 0.76 & 14 & 0.83 & 3 \\
\hline 11 & KCAKT & 0.79 & 9 & 0.74 & 10 & 0.77 & 13 & 0.84 & 2 \\
\hline 12 & ACI & 0.78 & 10 & 0.65 & 17 & 0.69 & 21 & 0.71 & 12 \\
\hline 13 & LWK & 0.78 & 10 & 0.79 & 6 & 0.85 & 6 & 0.75 & 9 \\
\hline 14 & MACT & 0.78 & 10 & 0.73 & 11 & 0.75 & 15 & 0.79 & 6 \\
\hline 15 & PFGRP & 0.78 & 10 & 0.83 & 3 & 0.72 & 18 & 0.64 & 17 \\
\hline 16 & STC & 0.78 & 10 & 0.78 & 7 & 0.79 & 11 & 0.73 & 10 \\
\hline 17 & QAUCE & 0.77 & 11 & 0.73 & 11 & 0.78 & 12 & 0.79 & 6 \\
\hline 18 & TAPCE & 0.77 & 11 & 0.61 & 19 & 0.63 & 25 & 0.81 & 4 \\
\hline 19 & EPC & 0.76 & 12 & 0.85 & 2 & 0.82 & 8 & 0.77 & 7 \\
\hline 20 & LBR & 0.76 & 12 & 0.74 & 10 & 0.8 & 10 & 0.75 & 9 \\
\hline
\end{tabular}




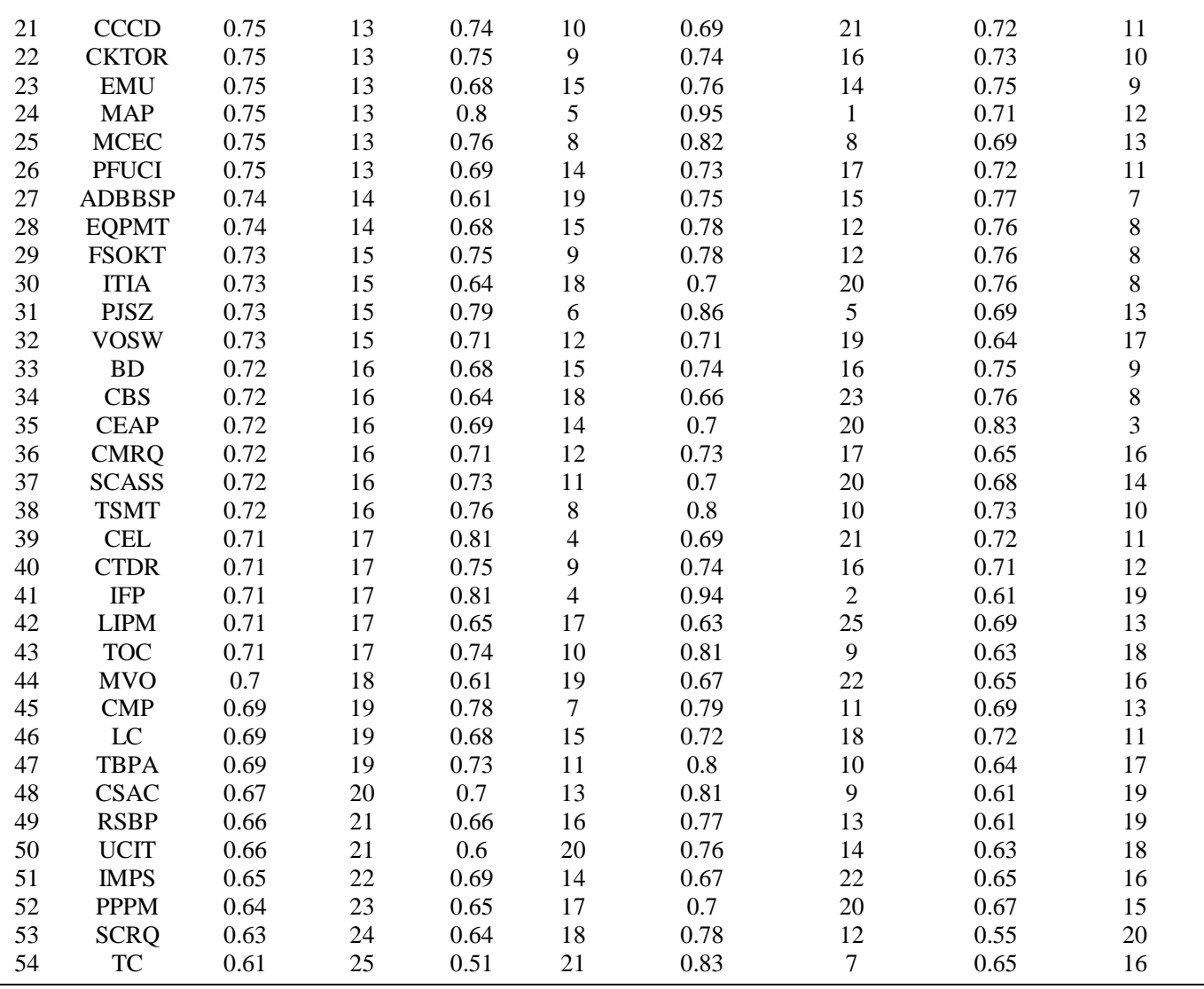

Source: Authors research fieldwork, 2013.

\section{For Correlation Analysis by clients and consultants ranking}

It was observed in table 2 that, the value of the Spearman correlation was positive and very high (0.997). The resulting $\mathrm{R}^{2}$ value was also very high at $99.40 \%$. Correlation was found to be significant at the 0.01 level. The " $R$ " value of 0.997 indicates a high association between the clients and consultants on the ranking of the essential factors affecting accuracy of pre-tender cost estimate. It was also empirically established that this relationship was statistically significant with P-value 0.000 which is less than 0.01 levels (2-tailed). The coefficient of determination $\left(\mathrm{R}^{2}\right)$ indicated about $99 \%$ relationship between the views of the respondents.

\section{For correlation Analysis by Client and Contractor Ranking}

It was also observed in the table 2 that, the value of the Spearman correlation was positive and very high (0.997). The resulting $\mathrm{R}^{2}$ value was also very high at $99.40 \%$. Correlation was found to be significant at the 0.01 level. The "R" value of 0.997 indicates a high association between the perspectives of the clients and contractors on the ranking of the essential factors affecting accuracy of pre-tender cost estimate. It was also empirically established that this relationship was statistically significant with P-value 0.000 which is less than 0.01 levels (2-tailed). The coefficient of determination $\left(\mathrm{R}^{2}\right)$ indicated about $99 \%$ relationship between the views of the respondents.

\section{Correlation Analysis for Consultants and Contractor Ranking}

It was observed in the table 2 that, the value of the Spearman correlation was positive and very high (0.996). The resulting $\mathrm{R}^{2}$ value was also very high at $99.20 \%$. Correlation was found to be significant at the 0.01 level. The " $R$ " value of 0.996 indicates a high association between the perspectives of the consultants and contractor on the ranking of the essential factors affecting accuracy of pre-tender cost estimate. It was also empirically established that this relationship was statistically significant with P-value 0.000 which is less than 0.01 levels (2-tailed). The coefficient of determination $\left(\mathrm{R}^{2}\right)$ indicated about $99 \%$ relationship between the views of the respondents. 
Table 2: Results of correlation analysis for Clients and Consultant, Client and Contractor and Consultant and Contractor on ranking.

\begin{tabular}{|c|c|c|c|c|c|c|c|}
\hline \multirow{2}{*}{$\begin{array}{l}\text { Analysis } \\
\text { No }\end{array}$} & \multicolumn{2}{|c|}{ Variables } & \multirow{2}{*}{$\begin{array}{c}\text { Spearman } \\
\text { Correlation (R) }\end{array}$} & \multirow{2}{*}{$\begin{array}{l}\mathbf{R}^{2-} \text { values } \\
(\%)\end{array}$} & \multirow{2}{*}{$\begin{array}{c}P \text { - } \\
\text { value }\end{array}$} & \multirow{2}{*}{$\begin{array}{l}\text { Strength of } \\
\text { Relationship }\end{array}$} & \multirow{2}{*}{ Remark } \\
\hline & $\mathbf{X}$ & $\mathbf{Y}$ & & & & & \\
\hline 4 & Clients & Consultants & 0.997 & $99.40 \%$ & 0.000 & Very Strong & SS \\
\hline 5 & Client & Contractor & 0.997 & $99.40 \%$ & 0.000 & Very Strong & SS \\
\hline 6 & $\begin{array}{c}\text { Consulta } \\
\text { nt }\end{array}$ & Contractor & 0.996 & $99.20 \%$ & 0.000 & Very Strong & SS \\
\hline
\end{tabular}

The following deductions were made:

\section{Discussion of findings}

There are numerous factors affecting pre-tender cost estimate in the study area but the most paramount among them are discussed based on the earlier analysis

The Experience and Skill Level of the Consultants; Project Teams Experience on the Construction Type; The experience of the project team as regards a particular construction type will enhance the amount of detail that is provided in the design made available to the estimator.

Clear and Detail Drawings and Specification and Completeness of Cost Information factor. It can thus be seen from the results that an estimate is only close to accuracy, if there is adequate cost data from which it is prepared. This will reduce uncertainties in preparing the estimate. Accuracy and Reliability of Cost Information. Availability of all Fields of Specialisation in a Project team is also important. This illustrates that having relevant qualified members of the project team at hand or at the conceptual stage, will aid the accuracy of the resultant estimate. Quality of Information and Flow Requirement is important and ranked $7^{\text {th }}$ which shows that the amount of information on all project related variables (cost data inclusive) to the estimator will enable him perform his work with minimum errors because estimate cannot be more accurate than the amount of available information.

Clear Scope definition for the Client was ranked $8^{\text {th }}$ in the ranking of the most important factor affecting pre-tender cost estimate. This result indicates a close agreement between the respondents. The scope of a project describes the level and extent of work required in a project, which is the client's definition of space, functionality, aesthetics, and quality requirement.

Financial Capabilities of the Client was ranked $8^{\text {th }}$ by all on the overall ranking of the respondents opinion. It shows that all respondents place premium on this factor given that the financial status of the client will guarantee steady cash flow to the contractor in carrying out his work, as well as aids the consultants in coming up with an estimate that is accurate. and in tune with the where with all of the client.

Completeness of Project Documents was ranked $9^{\text {th }}$ which implies that complete project documents optimize accurate estimating while social and cultural requirement was ranked $24^{\text {th }}$ by the respondents. The respondents do not believe that this factor has much significance on estimate accuracy. Type of Client was ranked the least important factor by all respondents at $25^{\text {th }}$ this result reveals an in-depth consideration of this factor by the consultants. They believe that the client's role in ensuring estimate accuracy is behemoth and keenly evaluated in their work, as against the view of other respondents (clients and contractor).

The result of the correlation analysis above revealed a very strong relationship between the clients, consultants, and contractors on the ranking of the factors affecting accuracy of pre-tender cost estimate. This implies that all the respondents share similar view on the reasons for inaccuracy in a cost estimate.

\section{Conclusion}

The ten most significant factors affecting accuracy of pre-tender cost estimate are:Experience and skill level of the consultants, Project teams experience on the construction type, clear and detail drawings and specification, completeness of cost information, accuracy and reliability of cost information, availability of all fields of specialization in a project team, quality of information and flow requirement, clear scope definition for the client, financial capability of the client, and completeness of project documents. Experience and skill level of the estimator is the most influencing factor affecting the accuracy of pre-tender cost estimate. This implies that to produce an accurate estimate encompassing available of detail information, skill and requisite experience of the estimator. It also requires Project team's experience on the construction. Knowledge and skill acquired over time by the design team on a particular construction type will enhance the amount of information they would provide to the estimator at the conceptual stage. 
There was no agreement on the ranking of the factors affecting accuracy of pre-tender cost estimate as proven by the high spearman correlation coefficients obtained. This implies that all respondents agree to the ranking (severity level) of the identified factors.

The research recommended that:

\section{Recommendations}

1. Clients should pay more attention to the cost estimating process by engaging the services of experienced and skilled professionals to undertake the consultancy services. This will enable them come up with most accurate cost estimates of the project.

2. Clients should endeavor to engage the services of all relevant professionals or specialist required for a particular project type, at conception stage to advice on all specialist works or construction. This is paramount to the realization of a feasible estimate.

3. Clients and consultants should provide all relevant documents before call for tender in order not to make room for contractors to price high to cover unknown risks.

4. Clients, consultants and contractor should keep themselves up to date with information on the current market conditions, by obtaining cost information from manufacturers and suppliers of building materials, components, and systems.

5. Clients, consultants, and contractor should build a cost information data base that would be updated on a regular basis. This will help improve the accuracy and reliability of cost estimates for future projects.

\section{References}

[1]. Abdal-Hadi, M. A. (2010). Factors affecting accuracy of pre-tender cost estimate in Gaza Strip. Unpublished master thesis in construction management, The Islamic University of Gaza-Palestine.

[2]. Akintoye, A. (2000). Analysis of Factors Influencing Project Cost Estimating Practice. Construction Management and Economics, 18(7) 77-89

[3]. Aliyu, B. (2005). Appraisal of Accuracy of Early Cost Estimate in Nigerian Construction Industry. Unpublished B.Sc Thesis, Quantity surveying Department, Ahmadu Bello University, Zaria.

[4]. Al- Khaldi, Z. S. (1990). Factors affecting the accuracy of construction costs estimating in Saudi Arabia. Unpublished master thesis in construction engineering and management, King Fahd University of Petroleum and Minerals, Dhahran, Saudi Arabia.

[5]. Antohie, E. (2009). Classes of construction cost estimates. Building Institutului Politehnic Din Iasi, Tomal LV(LIX), Fasc.. 21-26.

[6]. Ashworth, A. (1999). Cost Modelling. In Building in Value, Best, R. and De Valence, G. (eds). Arnold, London.

[7]. Asiedu, Y. \& Gu, P. (1998). Product life cycle cost analysis: state of the art review. International Journal of Production Research, 36 (4), 883-908.

[8]. Chan, S. L. \& Park, M. (2005). Project cost estimation using principal component regression, Construction Management and Economics, 23(5),295-304

[9]. Dysert, L.R. (2006). "Is accuracy an oxymoron?". AACE International Transaction 2006. EST01: 1-01.5.

[10]. Elhag T.M.S., Boussabaine, A. H., \& Ballal, T.M.. (2005). Critical determinants of construction tendering costs: quantity surveyors standpoint, International Journal of Project Management 23(7), 538-545.

[11]. Hendrickson, C. (2000). Project management for construction fundamental concepts for owners, engineers, architects and builders. Second Edition prepared for world wide web publication.

[12]. Iyer, K. C. and Jha, K. N. (2005). Factors affecting cost performance: evidence from Indian construction projects. International Journal of Project Management, Publisher Elsevier UK. 24(4), 283-295.

[13]. Liu, L.\& Zhu, K. (2007). Improving cost estimates of construction projects using phased cost factors. Journal of Construction Engineering and Management, 133(1), 91-95.

[14]. Marjuki, M. (2006). Computerized building cost estimating system, Unpublished Msc Thesis. University Teknologi Malaysia. Malaysia.

[15]. Momoh, A. O. (1980). Creative cost control for building. Council of the Nigerian institute of architects. May, 31-33.

[16]. Morenikeji, W. (2006). Research and Analytical Methods (for Social Scientists, Planners and Environmentalists). Jos University Press Limited, Jos.102, 180-182.

[17]. Oberlender, G. D., and Trost, S. M. (2001). Predicting accuracy of early cost estimates based on estimate quality. Journal of Construction Engineering and Management, 127( 3), 173-182

[18]. Odunsami, K.T.\& Onukwube, H.N. (2008). "Factors affecting the accuracy of pre-tender cost estimate in Nigeria. In: The Construction, Building and Real Estate Research Conference of the Royal Institution of Chartered Surveyors. Held at Dubling Institute of Technology, 4-5 September 2008

[19]. Oladokun, M. G, Oladokun, A. A, \& Odesola I. A (2010). The accuracy of pre-tender cost estimates of consultant quantity surveyors in Nigeria

[20]. Onukwube, H. N. (2002). An evaluation of of factors which influence tender prices of building works in nigeria. Journal of the Nigerian Institute of Quantity Surveyors, 40(3), 38-44.

[21]. Serpell, A. F. (2005). Improving conceptual cost estimating performance. AACE International Transactions EST.13.1 - 13.6

[22]. Shash, A. A., and Ibrahim, A. D. (2005). Survey of procedures adopted by A/E firms in accounting for design variables in early cost estimates, Journal of King Saud University, 18 (1), 1-17.

[23]. Skitmore, M. and Picken, D. (2000). The accuracy of pre-tender building price forecasts: an analysis of USA data. Australian Institute of Quantity Surveyors Refereed Journal. 4,(1) 33-39.

[24]. Trost, S. M. and Oberlender, G. D. (2003). "Predicting Accuracy of Early Cost Estimates Using Factor Analysis and Multivariate Regression." Journal of Construction Engineering and Management 129(2), 198 - 204. 
Appendix

Table 1. Most important factors affecting accuracy of pre-tender cost estimate

\begin{tabular}{ccccccccc}
\hline Rank & $\begin{array}{l}\text { Overall } \\
\text { Results }\end{array}$ & RII & Clients & RII & Consultants & RII & Contractor & RII \\
\hline 1 & ESLC & 0.9 & ESLC & 0.8 & ESLC & 0.7 & ESLC & 0.9 \\
2 & PTECT & 0.9 & PTECT & 0.8 & PTECT & 0.8 & PTECT & 0.8 \\
3 & CDDS & 0.9 & CDDS & 0.9 & CDDS & 0.7 & CDDS & 0.9 \\
4 & CCI & 0.8 & CCI & 0.8 & CCI & 0.6 & CCI & 0.8 \\
5 & ARCI & 0.8 & ARCI & 0.8 & ARCI & 0.8 & ARCI & 0.8 \\
6 & AAFS & 0.8 & AAFS & 0.8 & AAFS & 0.8 & AAFS & 0.8 \\
7 & QIFR & 0.8 & QIFR & 0.8 & QIFR & 0.9 & QIFR & 0.8 \\
8 & CSDC & 0.8 & CSDC & 0.8 & CSDC & 0.9 & CSDC & 0.8 \\
8 & FCC & 0.8 & FCC & 0.8 & FCC & 0.9 & FCC & 0.8 \\
9 & CPD & 0.8 & CPD & 0.8 & CPD & 0.8 & CPD & 0.8 \\
9 & KCAKT & 0.8 & KCAKT & 0.7 & KCAKT & 0.8 & KCAKT & 0.8 \\
10 & ACI & 0.8 & ACI & 0.7 & ACI & 0.7 & ACI & 0.7 \\
10 & LWK & 0.8 & LWK & 0.8 & LWK & 0.9 & LWK & 0.8 \\
10 & MACT & 0.8 & MACT & 0.7 & MACT & 0.8 & MACT & 0.8 \\
10 & PFGRP & 0.8 & PFGRP & 0.8 & PFGRP & 0.7 & PFGRP & 0.6 \\
10 & STC & 0.8 & STC & 0.8 & STC & 0.8 & STC & 0.7 \\
\hline
\end{tabular}

Source: Authors Research field work, 2013

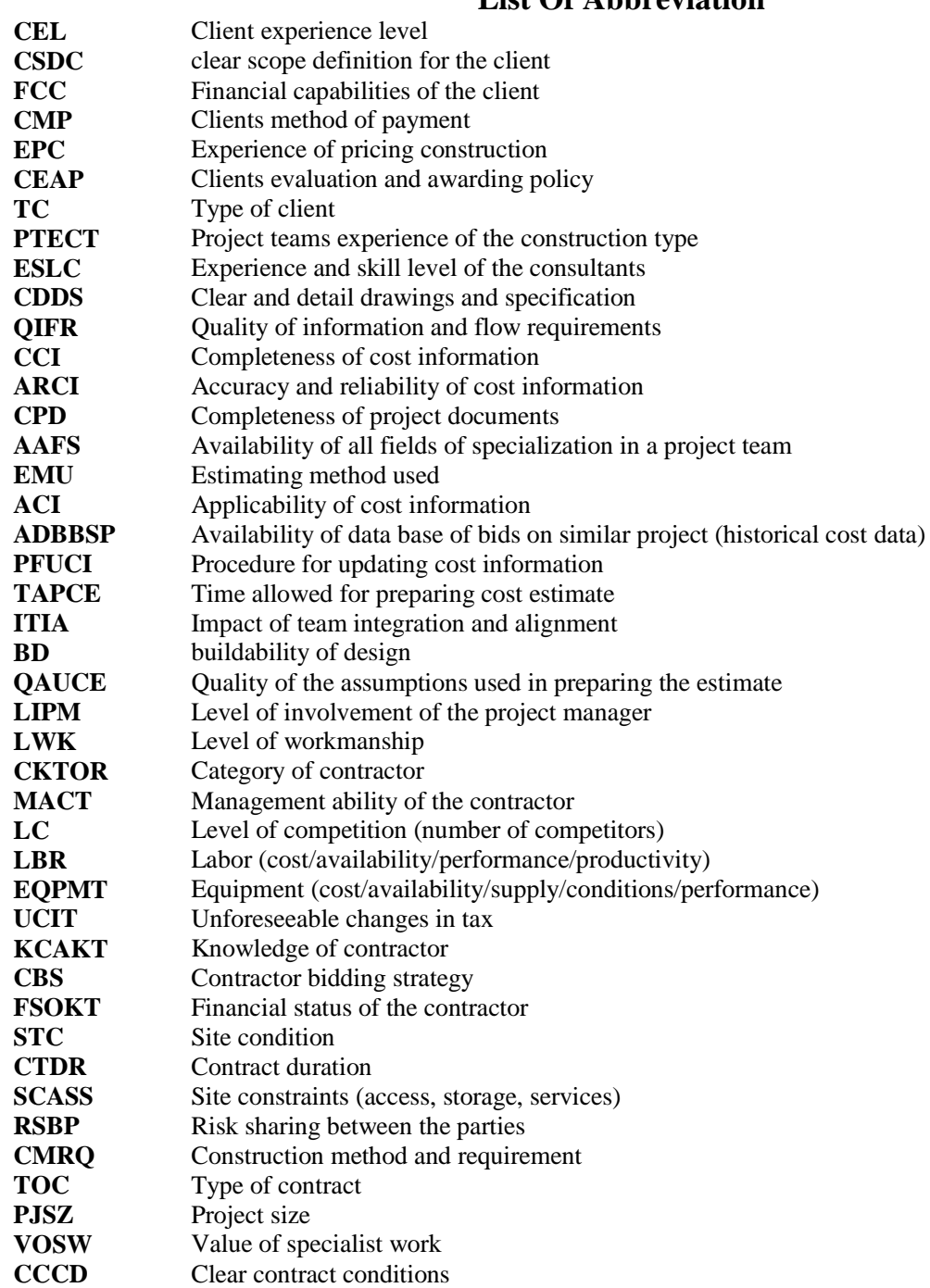


TSMT Tender selection method (open, etc)

IMPS Impact of project schedules

IFP Inflationary Pressures

TBPA Time between project announcement, bid submission and award of contract

SCRQ Social and cultural requirements

MCEC Market conditions/ economic climate

MAP Material availability and price

PPPM Poor procurement form and programming of material

CSAC Content of specification and arbitration clause

MVO Magnitude of variation order

PFGRP Political factor/ government requirements/ policy 